\title{
Mobile Response Team Saves Lives in Volcano Crises
}

The world's only volcano crisis re-
sponse team, organized and oper-
ated by the USGS, can be quickly mobi-
lized to assess and monitor hazards at
volcanoes threatening to erupt. Since
1986, the team has responded to more
than a dozen volcano crises as part of
the Volcano Disaster Assistance Pro-
gram (VDAP), a cooperative effort with
the Office of Foreign Disaster Assis-
tance of the U.S. Agency for Interna-
tional Development. The work of USGS
scientists with VDAP has helped save
countless lives, and the valuable les-
sons learned are being used to reduce
risks from volcano hazards in the
United States.

On April 2, 1991, after being dormant for 500 years, Mount Pinatubo volcano in the Philippines awoke with a series of steam explosions and earthquakes. Ten weeks later, on the morning of June 15th, Pinatubo exploded in a climactic volcanic eruption. Fiery avalanches of hot ash (pyroclastic flows) roared down the flanks of the volcano, and giant mudflows of ash (lahars) swept more than 30 miles down valleys. Cities and towns near Pinatubo were devastated by falling ash. Ash fall also inundated the two largest U.S. military bases in the Philippines. On Clark Air Force Base, which was home to more than 15,000 American servicemen and dependents, many buildings collapsed under the weight of rain-saturated ash. Facilities at the U.S. Naval

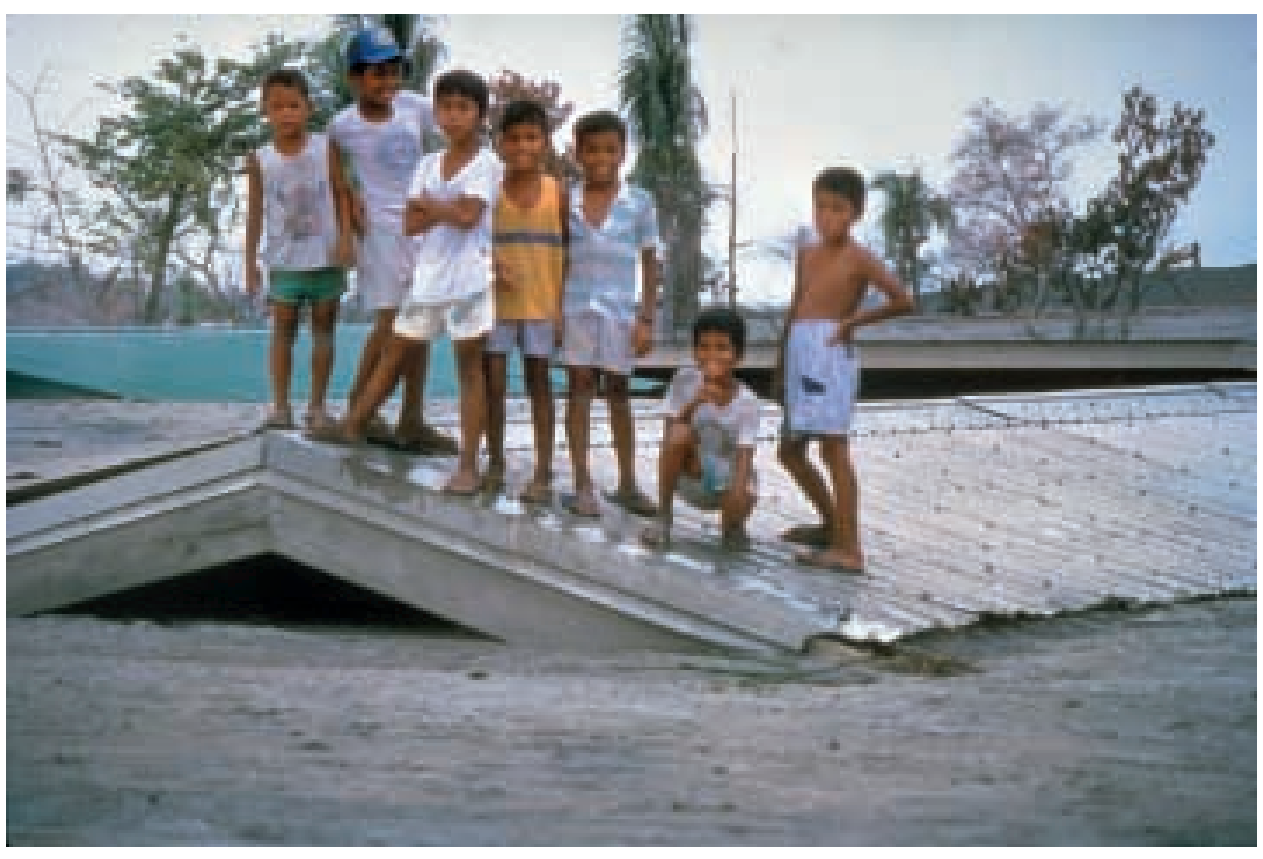

In June 1991, after 2 months of increasing unrest, Mount Pinatubo volcano in the Philippines exploded in a climactic volcanic eruption. Even months after the eruption, heavy rains caused giant mudflows of volcanic ash (lahars). These children stand atop their schoolhouse in the village of Bamban, which was buried by one of these lahars. In April 1991, after Pinatubo had reawakened, U.S. Geological Survey scientists with the Volcano Disaster Assistance Program's crisis-response team joined Philippine scientists to quickly evaluate the threat from the volcano. Their timely warnings permitted the safe evacuation of more than 75,000 people, including about 18,000 American servicemen and dependents from the two largest U.S. military bases in the Philippines, before Pinatubo's climactic eruption.
Station at Subic Bay, 25 miles from Pinatubo, were also severely damaged.

Despite the enormity of the devastation wrought by this explosive eruption, quick work by earth scientists helped keep the death toll low. Shortly after Mount Pinatubo's reawakening, U.S. Geological Survey (USGS) scientists with the Volcano Disaster Assistance Program's crisis response team arrived at
An avalanche of hot ash (pyroclastic flow) roars down the flank of the Soufrière Hills volcano on the Caribbean island of Montserrat. After the volcano stirred to life in the summer of 1995, a Volcano Disaster Assistance Program team worked with scientists from the Seismic Research Unit of the University of the West Indies, Trinidad, and the British Geological Survey to quickly set up a monitoring program. Almost half of the island's 12,000 residents have since been moved out of areas of high risk.

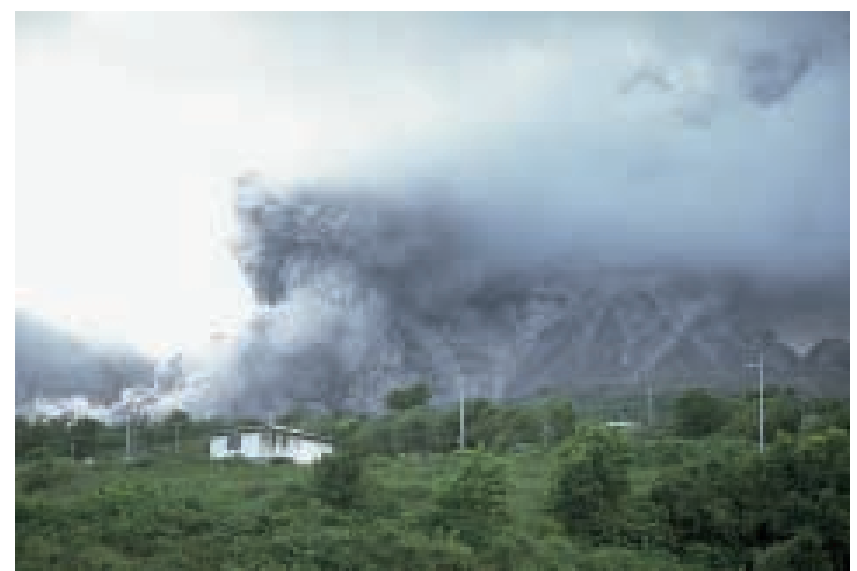

Clark Air Force Base. Once on the scene, they joined scientists from the Philippine Institute of Volcanology and Seismology, who had begun monitoring the volcano. This joint team worked quickly to evaluate the threat from Pinatubo, installing instruments to detect earthquakes and swelling on the mountain and mapping volcanic deposits in order to understand the volcano's eruptive history. Their evaluation enabled them to alert people in areas at risk and also provide critical advice to the Philippine Government and to U.S. military commanders at Clark Air Force Base and Subic Bay.

When data from monitoring instruments indicated that a large eruption was imminent, the scientists issued timely warnings that resulted in safe evacuation of more than 75,000 people before the volcano's climactic June 15 eruption. In addition to the thousands of lives saved, hundreds of millions of dollars in military aircraft and hardware were moved out of harm's way.

Volcanoes produce a wide variety of hazards that can kill people and destroy property. 
Large explosive eruptions can endanger people and property hundreds of miles away, affect global climate, and cause widespread economic losses. For example, the drifting ash cloud from the June 15, 1991, eruption of Mount Pinatubo damaged more than 20 passenger jetliners (including those of American air carriers), most of which were flying more than 600 miles from the volcano.

Since 1980, volcanic activity worldwide has killed more than 29,000 people, forced more than 1,000,000 to flee from their homes, and caused billions of dollars in economic losses. On average, about 10 eruptions a year cause significant damage and casualties, and eruptions powerful enough to cause major disasters happen several times a decade.

There are more than 1,500 potentially active volcanoes in the world, about 550 of which have erupted in historical times. Moreover, most of the truly devastating and strongest explosive eruptions since 1800 have occurred at volcanoes with no historical record of previous eruptions.

Despite the threat posed by volcanoes, only about 20 of the 550 historically active volcanoes in the world are monitored adequately, and fewer than one-third are monitored at all. As growing human populations encroach further into areas of greater volcano hazard, the potential for deadly disasters increases.

In the early 1980's, scientists at the USGS Cascades Volcano Observatory (CVO) in Vancouver, Washington, recognized that it was not economically feasible to fully monitor all potentially active volcanoes in the Pacific Northwest. To meet this problem, the USGS developed a suite of portable monitoring instruments that could be quickly deployed to a reawakening volcano. These instruments are used to detect and analyze earthquakes, ground deformation, mudflows, and volcanic gas emissions. The data from these instruments are supplemented by additional information from global positioning (GPS) satellites, weather radar, and other equipment.

In 1985, the eruption of Nevado del Ruiz volcano, Colombia, triggered giant, fast-moving lahars that killed more than 23,000 people. Following this tragedy, the U.S. Agency for

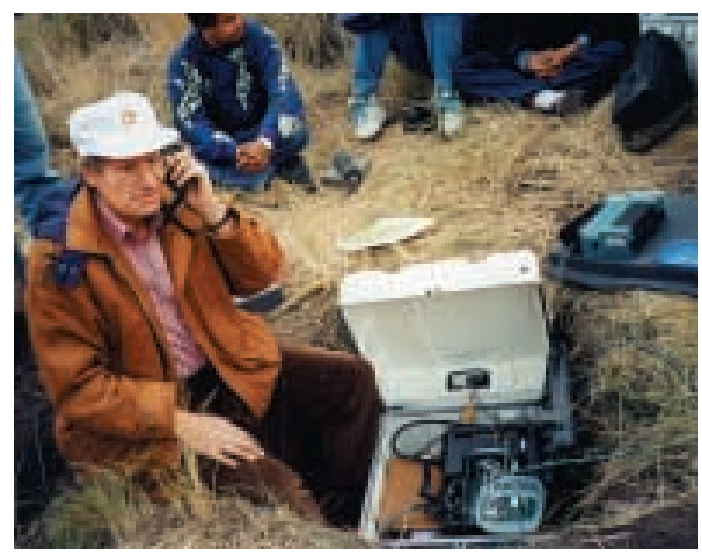

When majestic, 17,887-foot-high Popocatépet/ Volcano, near Mexico City, began to erupt intermittently in December 1994, the Mexican Government requested the aid of a scientific team from the Volcano Disaster Assistance Program (VDAP). "EI Popo" has erupted violently in the past, and a major explosive eruption today would put millions of people at risk. The VDAP team worked with local scientists lone of whom is seen here testing newly installed instruments) from the Centro Nacional de Prevencion de Desastres and the Universidad Nacional Autonoma de Mexico to set up a monitoring network on the volcano. Popocatépetl is now being intensively monitored. Should the volcano's current weak activity escalate, the effective forecasts and warnings made possible in part with VDAP's assistance may save countless lives and help lessen a massive, wide-ranging refugee crisis. bean, Africa, Asia, and the South Pacific. Most recently, VDAP teams have been providing assistance to Mexico and to the Caribbean island of Montserrat.

Although highly visible, the activities of VDAP are only one aspect of the USGS Volcano Hazards Program. The new techniques developed and the experience gained by scientists with VDAP in volcano crises overseas prepare the USGS to better protect people's lives and property from future eruptions of volcanoes in the United States.

John W. Ewert, C. Dan Miller, James W. Hendley II, and Peter H. Stauffer

Graphic design by

Sara Boore and Susan Mayfield

Banner design by Bobbie Myers

\section{COOPERATING ORGANIZATIONS}

U.S. Agency for International Development, Office of Foreign Disaster Assistance Governmental and scientific organizations in host countries

For more information contact: U.S. Geological Survey Cascades Volcano Observatory 5400 Mac Arthur Blvd., Vancouver, WA 98661 Tel: (360) 696-7693, Fax: (360) 696-7866 http://vulcan.wr.usgs.gov/

See also Volcanic Ash-Danger to Aircraft in the North Pacific (USGS Fact Sheet 030-97) 